Portland State University

PDXScholar

4-17-2016

\title{
Spatial and Temporal Variability of Contaminants Within Estuarine Sediments and Native Olympia Oysters: A Contrast Between a Developed and an Undeveloped Estuary
}

\author{
Elise F. Granek \\ Portland State University, graneke@pdx.edu \\ Kathleen E. Conn \\ U.S. Geological Survey \\ Elena B. Nilsen \\ U.S. Geological Survey \\ Lori Pillsbury \\ Oregon Department of Environmental Quality \\ Angela L. Strecker \\ Fortw \\ Portland State University, angela.strecker@wwu.edu \\ Part of the Environmental Sciences Commons \\ Lee us know how access to this document benefits you.
}

\section{Citation Details}

Granek, E. F., Conn, K. E., Nilsen, E. B., Pillsbury, L., Strecker, A. L., Rumrill, S. S., \& Fish, W. (2016). Spatial and temporal variability of contaminants within estuarine sediments and native Olympia oysters: $A$ contrast between a developed and an undeveloped estuary. The Science of the Total Environment, 557-558, 869-879.

This Article is brought to you for free and open access. It has been accepted for inclusion in Environmental Science and Management Faculty Publications and Presentations by an authorized administrator of PDXScholar. Please contact us if we can make this document more accessible: pdxscholar@pdx.edu. 


\section{Authors}

Elise F. Granek, Kathleen E. Conn, Elena B. Nilsen, Lori Pillsbury, Angela L. Strecker, Steven S. Rumrill, and William Fish

This article is available at PDXScholar: https://pdxscholar.library.pdx.edu/esm_fac/144 


\title{
Spatial and temporal variability of contaminants within estuarine sediments and native Olympia oysters: A contrast between a developed and an undeveloped estuary
}

\author{
Elise F. Granek ${ }^{\mathrm{a}, *}$, Kathleen E. Conn ${ }^{\mathrm{b}}$, Elena B. Nilsen ${ }^{\mathrm{c}}$, Lori Pillsbury ${ }^{\mathrm{d}}$, Angela L. Strecker ${ }^{\mathrm{a}}$, \\ Steve S. Rumrill ${ }^{\mathrm{e}}$, William Fish ${ }^{\mathrm{a}}$ \\ a Environmental Science E' Management, Portland State University, PO Box 751, Portland, OR 97207, United States \\ ${ }^{\mathrm{b}}$ Washington Water Science Center, U.S. Geological Survey, 934 Broadway, Suite 300, Tacoma, WA 98402, United States \\ c Oregon Water Science Center, U.S. Geological Survey, 2130 SW 5th Ave, Portland, OR 97207, United States \\ d Oregon Department of Environmental Quality, Laboratory E Environmental Assessment Program, 3150 NW 229th Ave, Suite 150, Hillsboro, OR 97124, United States \\ e Oregon Department of Fish and Wildlife, Marine Resources Program Oregon Department of Fish and Wildlife, 2040 SE Marine Science Drive, Newport, OR 97365, United States
}

\section{H I G H L I G H T S}

- Spatio-temporal variability in contaminant deposition and uptake poorly known

- Seasonal and spatial sampling of oysters (biosphere) for contaminants (anthroposphere)

- Sediment (lithosphere) sampled to identify biota-sediment accumulation factors

- Emerging and legacy contaminants varied spatially and by season (anthroposphere).

\section{G R A P H I C A L A B S T R A C T}

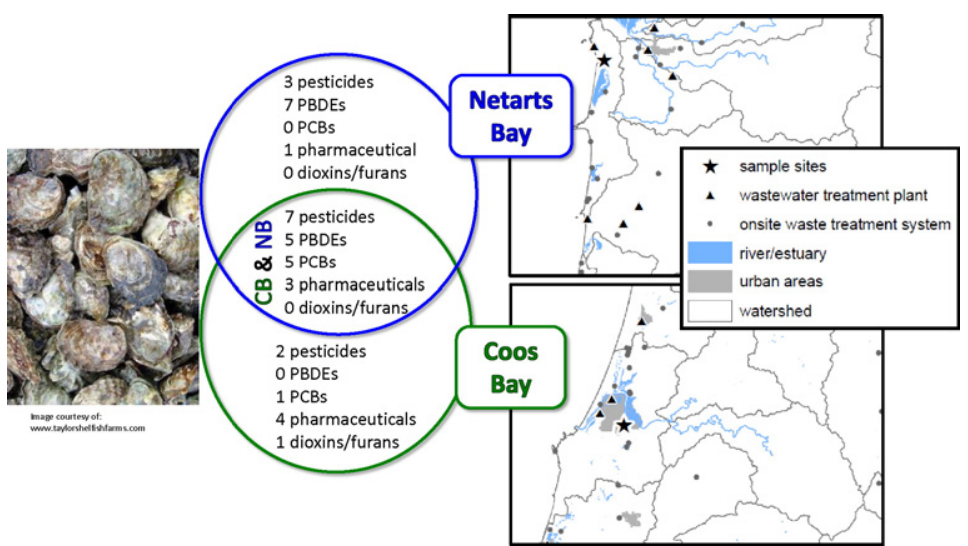

\begin{abstract}
A B S T R A C T
Chemical contaminants can be introduced into estuarine and marine ecosystems from a variety of sources including wastewater, agriculture and forestry practices, point and non-point discharges, runoff from industrial, municipal, and urban lands, accidental spills, and atmospheric deposition. The diversity of potential sources contributes to the likelihood of contaminated marine waters and sediments and increases the probability of uptake by marine organisms. Despite widespread recognition of direct and indirect pathways for contaminant deposition and organismal exposure in coastal systems, spatial and temporal variability in contaminant composition, deposition, and uptake patterns are still poorly known. We investigated these patterns for a suite of persistent legacy contaminants including polychlorinated biphenyls (PCBs) and polybrominated diphenyl ethers (PBDEs) and chemicals of emerging concern including pharmaceuticals within two Oregon coastal estuaries (Coos and Netarts Bays). In the more urbanized Coos Bay, native Olympia oyster (Ostrea lurida) tissue had approximately twice the
\end{abstract}

Keywords:

Alkylphenols

Bivalves

\section{Article history:}

Received in revised form 10 February 2016

Accepted 7 March 2016

Available online 17 April 2016

Editor: Adrian Covaci

\footnotetext{
* Corresponding author. (S.S. Rumrill).

E-mail addresses: graneke@pdx.edu (E.F.Granek), kconn@usgs.gov (K.E.Conn), enilsen@usgs.gov (E.B. Nilsen), Pillsbury.lori@deq.state.or.us (L. Pillsbury),Steven.S.Rumrill@state.or.us 
number of PCB congeners at over seven times the total concentration, yet fewer PBDEs at one-tenth the concentration as compared to the more rural Netarts Bay. Different pharmaceutical suites were detected during each sampling season. Variability in contaminant types and concentrations across seasons and between species and media (organisms versus sediment) indicates the limitation of using indicator species and/or sampling annually to determine contaminant loads at a site or for specific species. The results indicate the prevalence of legacy contaminants and CECs in relatively undeveloped coastal environments highlighting the need to improve policy and management actions to reduce contaminant releases into estuarine and marine waters and to deal with legacy compounds that remain long after prohibition of use. Our results point to the need for better understanding of the ecological and human health risks of exposure to the diverse cocktail of pollutants and harmful compounds that will continue to leach from estuarine sediments over time.

(C) 2016 Elsevier B.V. All rights reserved.

\section{Introduction}

Estuarine and marine ecosystems provide the foundation for an invaluable suite of ecosystem services, including provisioning, regulating, supporting, and cultural benefits (MEA, Millenium Ecosystem Assessment, 2005). Over $50 \%$ of the global population currently resides within $80 \mathrm{~km}$ of the coast, and ocean ecosystems are now recognized to simultaneously be of great importance and under increased pressure from human populations worldwide (UNEP, 2006). Pollutants including persistent legacy contaminants and those of emerging concern present an ongoing threat to marine ecosystems, and they have the potential to damage and degrade a variety of ecosystem benefits as well as pose a risk to human health (e.g., Fleming et al., 2006; Kimbrough et al., 2008). Persistent legacy contaminants such as dichlorodiphenyltrichloroethane (DDT) and polychlorinated biphenyls (PCBs) remain in the environment long after they are introduced and several congeners are potentially carcinogenic to humans and animals. Contaminants of emerging concern (CECs) include pharmaceuticals, natural and synthetic hormones, and chemicals in personal care products that, historically, had less data available, but which, in recent years, have been recognized as potentially serious environmental threats, particularly to the endocrine and reproductive systems (Glassmeyer et al., 2005). For example, the sex ratio of white sucker fish (Catostomus commersonii) was biased toward females and a large proportion of intersex fish was observed downstream of wastewater treatment plant effluent that contained a mixture of hormones and hormone-mimicking surfactant metabolites (Vajda et al., 2008). Chronic exposure of a lake population of fathead minnow (Pimephales promelas) to low concentrations $(5-6 \mathrm{ng} / \mathrm{L})$ of the potent synthetic estrogen $17 \alpha$-ethynylestradiol led to feminization of males, altered oogenesis in females, and ultimately, a near extinction of this species from the lake (Kidd et al., 2007).

Persistent contaminants and CECs may be introduced into the environment from a variety of sources. For example, although commercial use of PCBs is largely prohibited in the US, several uses are still authorized including incorporation into electrical and railroad transformers, natural gas pipelines, circuit breakers, and carbonless copy paper, and other applications (Oregon Department of Environmental Quality, ODEQ, 2003). Agricultural lands are an ongoing source of pesticides and herbicides, such as DDT and its breakdown products (dichlorodiphenyldichloroethane [DDD] and dichlorophenyldichloroethylene [DDE]), dieldrin, and chlordane. Household waste and dust are sources of polybrominated diphenyl ether (PBDE) flame retardants, which are used in motor vehicles, electronics and furniture (Schreder and La Guardia, 2014). Dioxins and furans are by-products emitted from a variety of industrial activities. Metals such as mercury may be transported to water bodies during wet deposition and overland runoff. Pharmaceuticals and personal care products (PPCPs) are discharged into the environment from households, hospitals, health-care facilities and other commercial operations. Consumers can excrete prescription or non-prescription pharmaceuticals at low concentrations, and excess pharmaceuticals are often flushed down the drain. Compounds in personal care products, such as alkylphenol-based surfactant metabolites present in soaps and detergents, are also washed away in sinks, showers, and lavatories. Consequently, wastewater treatment systems and onsite waste (i.e., septic) systems provide pathways of entry for these compounds into freshwater and marine systems (e.g., Paul et al., 1997; Conn et al., 2010). Several pharmaceuticals are also used to raise livestock; these compounds may be excreted by livestock and carried into rivers and streams (Barnes et al., 2002).

Little information is available on the occurrence of CECs and other contaminants in ecologically-sensitive areas such as estuarine and marine waters. Recent studies in Oregon revealed the presence of several different types of contaminants in the Willamette and Columbia Rivers which drain to the Oregon coast, within the Coos Estuary on the Oregon coast, and in wastewater effluent discharged into these waterbodies (Fig. 1; Hope et al., 2012; Morace, 2012; Nilsen et al., 2014; Pillsbury et al., 2015). However, very little information exists about contaminant concentrations in marine and estuarine organisms that occur in regions where the human population is low (i.e., less than 100,000 people along the entire Oregon coast). Historical sampling of marine organisms by the National Oceanographic and Atmospheric Administration (NOAA) Mussel Watch Program included mussel (Mytilus spp.) samples from six sites along the Oregon coast. This long term monitoring did not include CECs or Olympia oysters (Ostrea lurida; Kimbrough et al., 2008). Other coastal monitoring efforts such as EPA's National Coastal Condition Assessment do not include bivalves, which are important foundation species that filter feed and thereby accumulate chemical compounds. In the 1990s, sampling of softshell clams, oysters, and Dungeness crab in Coos Bay detected contaminants including butyltins and metals (ODEQ, personal communication).

Since exposure to multiple CECs with different modes of action may be a coast-wide ecological problem and potential human health issue, we examined the types and concentrations of contaminants and spatio-temporal variability of those compounds in two Oregon estuaries. Accumulation of persistent compounds and CECs in marine life has implications for ecological community structure, recreational and tribal shellfishing, and potential health consequences for human consumers (Guéguen et al., 2011; Gaw et al., 2014). The native Olympia oyster, the target species for this study, has drastically declined in abundance and distribution along the Pacific coast since the mid-1800s (White et al., 2009). In Oregon, several groups including NOAA, the South Slough National Estuarine Research Reserve, the Oregon Department of Fish and Wildlife, and The Nature Conservancy recently initiated actions to facilitate and guide restoration of Olympia oysters (Rumrill, 2010; Wasson et al., 2015). Recent sampling to examine CEC levels in Dungeness crabs (Cancer magister), California mussels (Mytilus californianus), and Oregon's coastal environment detected a suite of persistent legacy contaminants and CECs (Rodriguez del Rey, 2010; Granek, unpublished data).

Here we present new information about the chemical compounds and contaminant concentrations in sediment and oyster tissues from two Oregon estuaries that differ in the level of municipal, residential and industrial development. Our specific hypothesis is that persistent legacy contaminants and CECs will be elevated in sediments and oysters sampled from Coos Bay where municipal and residential development 


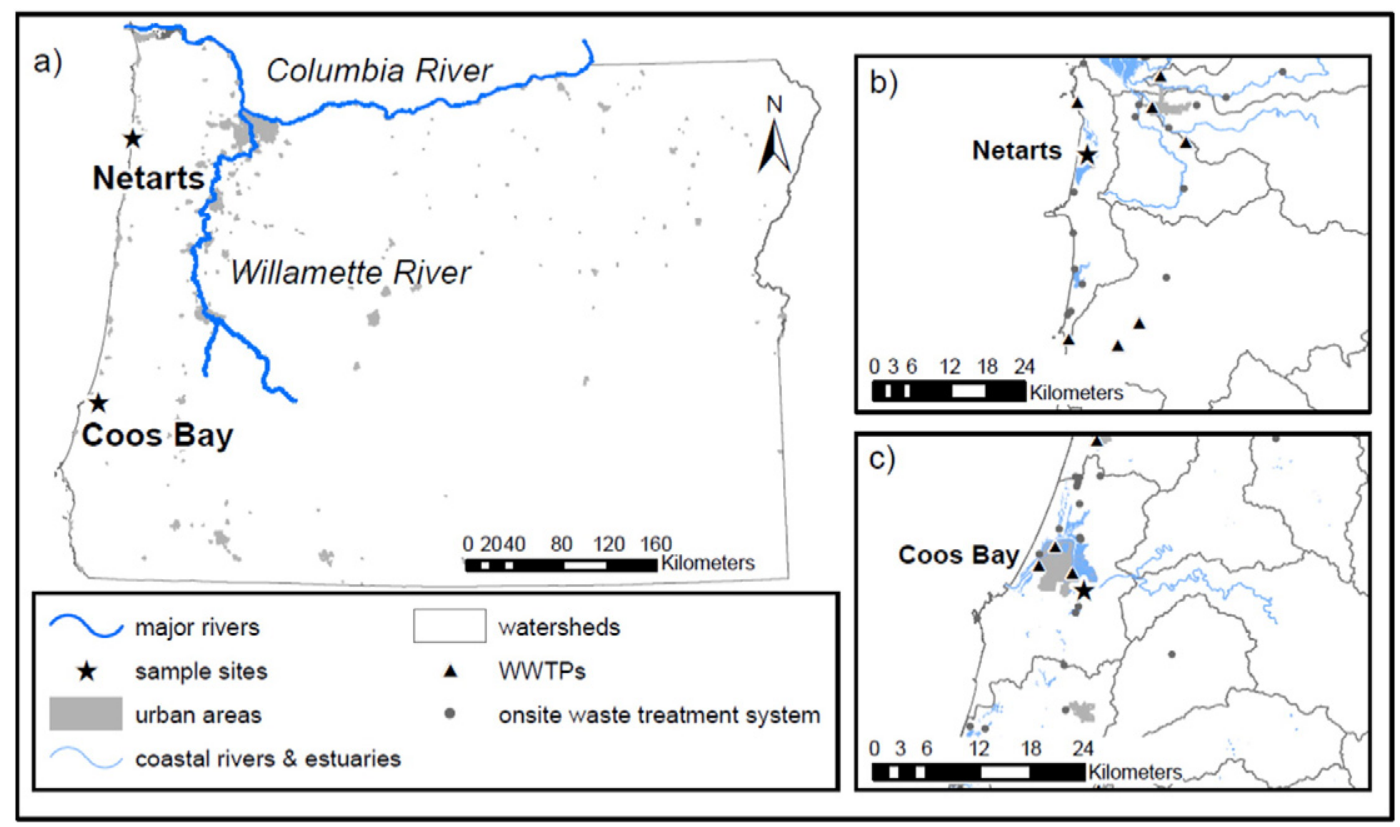

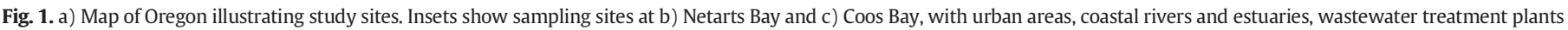

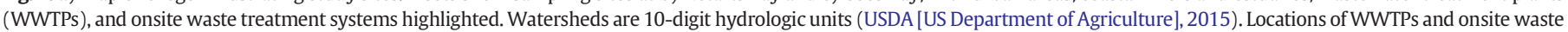
treatment systems obtained from Oregon Department of Environmental Quality (2015).

is extensive. Although moderate in urbanization compared to other U.S. estuaries, Coos Bay is considered urban is comparison to other Oregon estuaries. In contrast, we anticipate that contaminant levels will be low in Netarts Bay where residential development is much lower and industrial operations are non-existent. Both sites are inhabited by significant and recovering populations of native Olympia oysters. We also expect that seasonal variability (e.g., from precipitation) and spatial variability (e.g., from land-use practices and population density) contribute to variability in the concentrations of environmental contaminants observed in the estuarine sediments and oyster tissues.

\section{Methods}

\subsection{Study sites}

Olympia oysters (Ostrea lurida) were historically abundant but have been lost from much of their native range along the US West Coast (Beck et al., 2011). In Oregon, populations persist in Coos Bay, Yaquina Bay, and Netarts Bay where native oyster restoration efforts and commercial shellfish operations have helped enhance the populations. We focused our sampling within Coos Bay and Netarts Bay (Fig. 1, Table 1) where sufficient numbers of Olympia oysters can be collected without harm to the recovering populations.

Netarts Bay is a small lagoonal estuary with a very low human population density (Table 1). Rural residential development is concentrated along the north and eastern shoreline, and scattered homes and small farms occur throughout the watershed. Less than 1000 residents inhabit the shoreline and watershed of Netarts Bay (U.S. Census Bureau, 2008), which does not receive any major discharges from either WWTPs or industries. The upper Netarts watershed is managed primarily for commercial forest production $\left(1914 \mathrm{~km}^{2} ; 65.9 \%\right)$ and the lower elevation lands are used predominantly for agriculture $\left(62 \mathrm{~km}^{2} ; 2.1 \%\right)$. Netarts Bay is not dredged and is classified as a Conservation Estuary by the Oregon statewide land-use planning system.

In contrast, Coos Bay, a drowned river-mouth estuary, is the largest estuary located entirely within Oregon, and the surrounding area is inhabited by the largest human population along the Oregon coast (Table 1). In 2010, a total of about 25,000 residents lived in the primary cities of Coos Bay and North Bend (U.S. Census Bureau, 2008), and many thousand more people reside in smaller towns located along the shoreline (e.g., Charleston, Barview, Empire, Glasgow, Eastside, Englewood, and Millington). The estuary receives effluent from two major WWTPs as well as stormwater run-off from the surrounding population center. The coastal watershed is managed for commercial forest production with a small amount of agricultural lands (Table 1). The Coos estuary has experienced a long legacy of shoreline municipal development and industrial operations, including development of the cities and bay as centers for commercial fishing and seafood processing, shipbuilding, maritime commerce, railroad operations, commercial trucking, wood products mills, and shoreline dairy operations. The navigational channel of the Coos estuary is routinely dredged to a depth of $45 \mathrm{ft}$ below MLLW (mean low water), and the bay is classified as a Deep-Draft Development Estuary by the Oregon statewide land-use planning system. Coos Bay currently leads the state of Oregon in commercial mariculture of Pacific oysters (Crassostrea gigas).

\subsection{Field sampling}

Oyster samples were collected three times (summer 2013, fall 2013 and spring 2014) at each site from a single location in the respective estuary (Table 2). Olympia oysters were collected during low tide at sites identified by ODFW as having sufficient numbers of oysters to support

Table 1

Characteristics of Coos and Netarts Bays (USEPA, 2009). OWTS = onsite waste treatment system, WWTP = wastewater treatment plant.

\begin{tabular}{lll}
\hline Characteristic & Netarts Bay & Coos Bay \\
\hline General location & Northern Oregon coast & Southern Oregon coast \\
Estuary classification & Conservation & Deep draft development \\
Area of estuary & $9.4 \mathrm{~km}^{2}$ & $54 \mathrm{~km}^{2}$ \\
Watershed area & $2,951 \mathrm{~km}^{2}$ & $2,332 \mathrm{~km}^{2}$ \\
Annual precipitation & $229 \mathrm{~cm}$ & $163 \mathrm{~cm}$ \\
Shoreline population & $<1000$ & $>25,000$ \\
Land use & Forest, rural residential, & Residential, industrial \\
& agricultural & \\
Distance to WWTP & $6.0 \mathrm{~km}$ & $2.1 \mathrm{~km}$ \\
OWTS density in watershed & 0.055 OWTS/sq km & 0.021 OWTS/sq km \\
\# of WWTPs in & 0 & 3 \\
watershed & &
\end{tabular}


collection of 70-100 individuals (T. D'Andrea, pers. comm.). All members of the collection team wore gloves and hats during field collection, and gloves, hats and masks were worn during sample processing to prevent contamination. Ambient seawater $(1 \mathrm{~L})$ was also collected at low tide from the immediate vicinity of the oyster bed to provide rinse water for the processing of oyster gut contents in the laboratory. The Olympia oysters had shell lengths between $30-46 \mathrm{~mm}$ and a total wet weight of 4-14 g (shell + tissue).

Sediment samples were collected one time during summer 2013 at low tide from tidal flat areas adjacent to the oyster beds. The sediment samples were collected at one location per estuary at a recently drained intertidal area that lacked emergent terrestrial vegetation, and the substrata consisted largely of unconsolidated mud. A $1 \mathrm{~m}^{2}$ quadrat was selected at random from the tideflat, and a plastic scoop was used to remove the uppermost $5 \mathrm{~cm}$ of sediment from five locations within the quadrat. Each sediment sample was sieved in the field through a $2 \mathrm{~mm}$ stainless steel mesh into a stainless steel mixing bowl, homogenized by stirring, transferred into a clean glass collection jar, and placed on ice. A new scoop was used for each sample site, and the stainless steel sieve and bowl were rinsed between sites with de-ionized water and then rinsed with ambient seawater.

The oyster and sediment data collected in this study were complemented by similar data for soft shell clams collected by Oregon Department of Fish \& Wildlife (ODFW) and analyzed by ODEQ.

\subsection{Sample preparation}

Individual Olympia oysters were collected by hand, wrapped in aluminum foil and transported on dry ice to the laboratory where they were weighed and measured. Oysters prepared for CEC analysis were subsequently shucked, dissected to expose the gut, and rinsed with ambient seawater to remove mud, sand, and food particles. Groups of 10 oysters were then double packaged in foil wraps, bagged, and frozen at $-80{ }^{\circ} \mathrm{C}$. Oyster samples collected in summer 2013 were split into two groups: (1) half were sent by vehicle to the Oregon Department of Environmental Quality (ODEQ) analytical lab in Hillsboro, OR, USA for measurement of persistent contaminants; and (2) half were shipped (via air/ground transportation) frozen on wet ice to AXYS Analytical Laboratory in Sidney, British Columbia, Canada, for CEC analysis. Per EPA protocol (USEPA, 2000), oysters selected for analysis of metals, pesticides and other legacy contaminants were not dissected upon return from the field. Oyster samples collected in fall 2013 and spring 2014 were only sent to AXYS Analytical Laboratory for analysis. Tissue and sediment samples analyzed by ODEQ were prepared for analysis by freeze drying and storage at $-20^{\circ} \mathrm{C}$. Oyster tissue samples processed by the AXYS Analytical Laboratory were also stored at $-20^{\circ} \mathrm{C}$.

Table 2

Chemical groups analyzed by season and sample type. (Analyzing laboratory: ODEQ Oregon Department of Environmental Quality; AXYS, AXYS Analytical, LTD. PCBs=polychlorinated biphenyls; $\mathrm{PBDEs}=$ polybrominated diphenyl ethers; $\mathrm{PPCPs}=$ pharmaceuticals and personal care products. See Appendix Tables for complete list of parameters.)

\begin{tabular}{|c|c|c|c|}
\hline \multirow[t]{2}{*}{ Season } & \multicolumn{2}{|l|}{ Sample type } & \multirow{2}{*}{$\begin{array}{l}\text { Analyzing } \\
\text { laboratory }\end{array}$} \\
\hline & Oyster & Sediment & \\
\hline \multirow[t]{6}{*}{ Summer 2013} & Metals & Metals & ODEQ \\
\hline & PCBs & PCBs & ODEQ \\
\hline & PBDEs & PBDEs & ODEQ \\
\hline & Dioxins/furans & Dioxins/furans & ODEQ \\
\hline & Pesticides & Pesticides & ODEQ \\
\hline & PPCPs & No sample & AXYS \\
\hline Fall 2013 & $\mathrm{PPCPs}^{\mathrm{a}}$ & No sample & AXYS \\
\hline \multirow[t]{2}{*}{ Spring 2014} & PPCPs & No sample & AXYS \\
\hline & Alkylphenols & No sample & AXYS \\
\hline
\end{tabular}

a Analyzed at Coos Bay only.

\subsection{Analysis}

Sediments and oyster tissue collected from Netarts and Coos Bays were analyzed for metals, PCBs, PBDEs, pesticides and dioxins/furans, PPCPs, and alkylphenols as described in Table 2 (individual compounds listed in the Supporting Information). Oyster tissue samples were analyzed at AXYS Analytical for PPCPs and alkylphenols. Detailed information about the analytical methodology is available in the Supporting Information. Briefly, samples were analyzed for a total of 59 PPCPs by solvent extraction followed by analysis by high performance liquid chromatography coupled to a triple quadrupole mass spectrometer (LC-MS/MS).

Oyster tissue samples from spring 2014 were analyzed for four alkylphenols (4-nonylphenol, 4-n-octylphenol, 4-nonylphenol monoethoxylate, and 4-nonylphenol diethoxylate) at AXYS Analytical by solvent extraction followed by LC-MS/MS.

Tissue samples from summer 2013 were analyzed at the ODEQ laboratory for several classes of inorganic and organic contaminants. Following EPA 6020A, tissue samples were freeze dried, digested and analyzed for three metals (arsenic, cadmium, and selenium) on an inductively coupled plasma mass spectrometer. Mercury in oyster tissue was analyzed following EPA 7473 on a thermal decomposition atomic absorption spectrometer. Digestion and analysis for inorganic arsenic occurred following EPA 1632A on an atomic absorption spectrometer. Samples were extracted for four main classes of organic contaminants, PCBs (EPA 1668), PBDEs (EPA 1614), dioxins and furans (EPA 1613) and legacy pesticides (EPA 1699), and analyzed on a gas chromatograph high resolution mass spectrometer; Butyltins were extracted and analyzed on a gas chromatograph flame photometric detector following the CAS SOC-Butyl internal reference (based on EPA 515.4 Rev 1) by ALS Environmental Laboratory in Kelso, Washington (certified by the Oregon Laboratory Accreditation Program; ORELAP). Tissue results are reported in wet weight $\left(C_{w}\right)$ based on the following: $C_{w}=\left(C_{d} * \%\right.$ solids) / 100 , where $C_{d}=$ concentration measured in dry weight.

Sediment samples from summer 2013 were analyzed by the ODEQ laboratory for the same classes of contaminants following the same methods as the tissue samples. Fifteen additional metals and mercury were analyzed from the sediments, and inorganic arsenic was not analyzed in sediment. Butyltins in sediment were measured following the same method used for oyster tissues. Sediment results are reported in dry weight.

\subsubsection{Quality control and reporting}

Triplicate samples of tissue were analyzed at all sites during all seasons. Quality control samples were included with each batch of 20 samples for all methods in accordance with each laboratory's quality assurance plan. Each batch contained a laboratory blank, blank spike, matrix spike, and matrix spike duplicate. The inorganic arsenic method also included a laboratory duplicate. A tissue or sediment standard or certified reference material was included in each batch of samples analyzed by ODEQ (Table 3). In contrast, sample batches for mercury analysis included a laboratory blank, laboratory duplicate, and standard reference material. When available, isotopically-labeled surrogate compounds were added to AXYS Analytical samples prior to extraction. The use of isotope dilution/recovery correction in each sample allows for compensation of loss of a target compound during the extraction and cleanup process.

At the ODEQ laboratory, initial instrument calibrations included at least three non-zero standards for linear calibrations and five nonzero standards for non-linear calibrations. Calibration verifications were performed and utilized second source standards when available.

All quality control sample results were compared to acceptable limits for the laboratory protocol. If results were outside acceptable ranges, any affected sample results were flagged according to methodspecific requirements, project reporting requirements, or laboratory standard operating procedures. Surrogate spike recoveries were 
Table 3

Methods used to analyze legacy contaminants in oyster tissue and sediment samples.

\begin{tabular}{lll}
\hline Matrix & Method(s) & Standard reference material \\
\hline Tissue & EPA 1668, 1614, 1699 & NIST SRM 1947, Lake Michigan fish tissue \\
Tissue & EPA 1613 & None available \\
Tissue & EPA 6020A & NIST SRM 2976, mussel tissue \\
Tissue & EPA 1632A & $\begin{array}{l}\text { CNRC CRM TORT-2, lobster hepatopancreas } \\
\text { tissue }\end{array}$ \\
Tissue & EPA 7473 & CNRC CRM DOLT 2, dogfish liver \\
Sediment & EPA 1668, 1613,1699 & NIST SRM 1944, NY/NJ waterway sediment \\
Sediment & EPA 1614 & None available \\
Sediment & EPA 6020A & NIST SRM2702, inorganics in marine sediment \\
Sediment & EPA 7473 & NIST SRM 2709, San Joaquin soil \\
\hline
\end{tabular}

generally acceptable and are reported in the Supporting Information. Only acceptable quality data are reported below. For example, results are reported as not detected if the concentration in an environmental sample was less than two times the concentration detected in the associated laboratory blank sample. Eythromycin- $\mathrm{H}_{2} \mathrm{O}$, 4-nonylphenol and 4-nonylphenolmonoethoxylate were detected in laboratory blank samples, resulting in censoring of one or more environmental samples. For AXYS Analytical methods, concentrations in environmental samples that were less than two times the blank detection limit and were not detected in the blank sample were qualified with a "^" in Table 4 , and were not included as detections in subsequent calculations and associated figures, with the exception of the PCA analysis. For ODEQ methods, only detections above the reporting limit are included, with the exception of reporting for the Total Substituted TEQ. This calculation involves the sum of isomers, some of which may have a concentration above the instrument signal to noise ratio but below the reporting limit. ODEQ data of known quality (Category "A") and data of known but lesser quality (Category "B") are reported while data of unacceptable quality (Category "C") are not reported. Original data, associated qualifiers, and qualifier descriptions for ODEQ analyses are housed in ODEQ Laboratory Data Repository and are reported in the Supporting Information. Finally, we examined spatial and temporal patterns in PPCP occurrence in oyster tissue using multivariate statistics. We performed a principal components analysis (PCA) on the concentrations of PPCPs in oysters during the spring and summer sampling periods, as we were limited to time

Table 4

Concentrations ( $\mu \mathrm{g} / \mathrm{kg}$ wet weight) of detected alkylphenols and pharmaceuticals in oyster tissue by season and location. ND, not detected. Bold indicates an unqualified detection.

\begin{tabular}{|c|c|c|c|}
\hline \multirow[t]{2}{*}{ Parameter } & \multirow[t]{2}{*}{ Season } & \multicolumn{2}{|l|}{ Location } \\
\hline & & Netarts Bay & Coos Bay \\
\hline 4-Nonylphenol* & Spring & 31.6 & $19.5,20.0$ \\
\hline 4-n-Octylphenol ${ }^{*}$ & Spring & $1.38,1.52,1.93$ & $1.94,2.06,2.35$ \\
\hline Nonylphenolmonoethoxylate* & Spring & ND & $2.22,2.50$ \\
\hline Nonylphenoldiethoxylate* & Spring & $\begin{array}{l}0.533,0.765 \\
0.879^{\wedge}\end{array}$ & $0.861,0.921,0.935^{\wedge}$ \\
\hline Azythromycin & Spring & 3.24 & $0.898^{\wedge}, 2.12$ \\
\hline Sulfamethoxazole & Spring & ND & 2.76 \\
\hline Furosemide & Spring & ND & $18.7^{\wedge}$ \\
\hline Hydrochlorothiazide & Spring & $6.77^{\wedge}$ & ND \\
\hline Ibuprofen & Spring & ND & $10.5^{\wedge}$ \\
\hline Naproxen & Spring & $1.92^{\wedge}$ & $1.91^{\wedge}$ \\
\hline Cloxacillin & Summer & $\begin{array}{l}5.13 \\
\text { (estimated) }\end{array}$ & ND \\
\hline Diphenhydramine & Summer & ND & $0.403^{\wedge}, 0.505,0.512$ \\
\hline Erythromycin- $\mathrm{H}_{2} \mathrm{O}$ & Summer & $0.960^{\wedge}$ & $0.939^{\wedge}$ \\
\hline Sulfadiazine & Summer & $0.782,0.785^{\wedge}$ & $0.703,0.770^{\wedge}$ \\
\hline Virginiamycin M1 & Summer & $3.94^{\wedge}$ & ND \\
\hline Naproxen & Summer & ND & 3.39 \\
\hline Triclocarban & Fall & Not analyzed & $1.61^{\wedge}$ \\
\hline Diphenhydramine & Fall & Not analyzed & $0.26^{\wedge}$ \\
\hline
\end{tabular}

* Sampled in Spring 2014 only.

Concentration less than two times the detection limit frames when the same analytes were tested at both sites. The PCA was performed in R version 3.1.3 (R Development Core Team, 2015).

Biota-sediment accumulation factors (BSAFs) compare the concentration of a given contaminant measured in an organism to the concentration of the contaminant measured in the sediment (Shirneshan and Bakhtiari, 2012). BSAFs were calculated by dividing the summer 2013 oyster tissue concentration by the sediment concentration.

\section{Results}

\subsection{Oyster tissue}

Chemical detections and concentrations varied by estuary, time period and compound category. All of the compound groups, with the exception of dioxins/furans, were detected in oyster tissue during at least one season (Tables 4 and 5). Of the CECs, three (of 4 tested) alkylphenols and five (of 59) PPCPs were detected. The pharmaceuticals detected included antibiotics, an antihistamine, and an antiinflammatory substance (Table 4 ). One (of 4 ) heavy metals (mercury) and 13 (of 69) pesticides, including four DDT breakdown products were detected. Twelve (of 37) PBDE congeners and 102 (of 194) PCB congeners were detected (Table 5). The only individual dioxin or furan detected above the reporting limit was octachlorodibenzodioxin (OCDD) in oyster tissue from Coos Bay.

The pattern of contaminant detections varied between estuaries (Fig. 2) with no clear signal of higher contamination at the urbanized site across all contaminant categories. For example, in summer 2013, nearly twice the number of PCB congeners were detected in oyster tissue from Coos Bay as compared to Netarts Bay. A total of 102 PCB congeners with a summed concentration of $59,500 \mathrm{ng} / \mathrm{kg}$ dry weight were detected in Coos Bay. In contrast, only 55 PCB congeners with a summed concentration of $7690 \mathrm{ng} / \mathrm{kg}$ dry weight were detected in Netarts Bay. This difference in concentration is not fully explained by lipid content, which averaged $1.45 \%$ of wet weight in Coos Bay and $0.99 \%$ of wet weight in Netarts Bay oysters. On the other hand, we observed more PBDE detections and higher concentrations in Netarts Bay (Table 5, Fig. 2). Twelve PBDE congeners were detected in Netarts Bay for a summed concentration of $54,300 \mathrm{ng} / \mathrm{kg}$ dry weight. Only five PBDE congeners were detected in Coos Bay with a summed concentration of $5460 \mathrm{ng} / \mathrm{kg}$, approximately ten times lower than the concentration in Netarts Bay (Table 5). Three PBDE congeners with Oregon Health Authority screening values were detected in oyster tissue (at levels below the screening values): congeners 99,153 , and 209, as well as 9 other congeners: $15,17,28,47,49,66,71,100$, and 154 (Table 5).

The pharmaceuticals detected during summer 2013 (diphenhydramine and naproxen) differed from those detected during spring 2014 (azithromycin and sulfamethoxazole), and no pharmaceuticals were detected in oyster tissue collected during fall 2013. No personal care products were detected. The detection limits at AXYS Analytical Laboratory are extremely low, typically less than $0.5 \mu \mathrm{g} / \mathrm{kg}$, so lack of detection is unlikely due to insufficient sensitivity. Our examination of seasonal and spatial patterns of PPCPs in oyster tissue using principal components analysis demonstrates that the two sites were similar in the summer but highly divergent in the spring (Fig. 3).

\subsection{Bed sediment}

Individual compounds from each of the persistent chemical groups were detected in sediment collected in summer 2013 (Table 6). Twelve (of 17 tested) heavy metals, nine (of 69) pesticides, two (of 17) congeners of dioxins/furans, 2 (of 37) PBDEs, and 84 (of 194) PCB congeners were detected in sediments collected in summer 2013 (Table 6).

Occurrence and concentrations in the sediment were similar between sites for some compound groups and varied between sites for other compound groups. Occurrence and concentrations of metals and dioxins/furans were similar between sites. Eleven metals were detected 
Table 5

Concentrations ( $\mathrm{ng} / \mathrm{kg}$ ) of detected legacy contaminants in oyster tissue collected from Netarts Bay and Coos Bay, OR, summer 2013. na $=$ not applicable; $\mathrm{ND}=$ not detected; NAF = not analyzed for. *Oregon Health Authority Standard Operating Guide, 2013.

\begin{tabular}{|c|c|c|c|c|c|}
\hline \multirow{3}{*}{ Parameter } & \multirow{3}{*}{$\begin{array}{l}\text { OR health authority } \\
\text { screening values* }\end{array}$} & \multicolumn{4}{|c|}{ Location } \\
\hline & & \multicolumn{2}{|c|}{ Netarts bay } & \multicolumn{2}{|c|}{ Coos bay } \\
\hline & & $\begin{array}{c}\text { wet } \\
\text { weight }\end{array}$ & $\begin{array}{c}\text { dry } \\
\text { weight }\end{array}$ & $\begin{array}{c}\text { wet } \\
\text { weight }\end{array}$ & $\begin{array}{c}\text { dry } \\
\text { weight }\end{array}$ \\
\hline Percent lipids (wet weight) & & 0.991 & na & 1.45 & na \\
\hline Percent solids & & 16.8 & na & 21.6 & na \\
\hline \multicolumn{6}{|c|}{ Metals } \\
\hline Mercury, total & 200,000 & 14,000 & 833,000 & 48,000 & 222,000 \\
\hline \multicolumn{6}{|c|}{ Pesticides } \\
\hline $2,4^{\prime}-\mathrm{DDD}$ & & 14.6 & 86.9 & 40.3 & 187 \\
\hline $4,4^{\prime}-\mathrm{DDD}$ & $\begin{array}{c}1.2 \times 10^{6} \\
c\end{array}$ & 48.3 & 288 & 119 & 551 \\
\hline $2,4^{\prime}-\mathrm{DDE}$ & 4,4' - DDE, $2,4^{\prime}$ - and $4,4^{\prime}$ - DDT) & 10.0 & 59.5 & ND & ND \\
\hline $4,4^{\prime}-\mathrm{DDE}$ & & 355 & 2,110 & 211 & 977 \\
\hline alpha-BHC & & 32.5 & 193 & ND & ND \\
\hline beta-BHC & & 34.7 & 207 & 30.5 & 141 \\
\hline alpha-Chlordane & & 19.1 & 114 & 49 & 227 \\
\hline cis-Nonachlor & (total: cis - and trans - chlordane, & ND & ND & 19.1 & 88.4 \\
\hline $\begin{array}{l}\text { gamma-Chlordane+trans- } \\
\text { Nonachlor }\end{array}$ & $\begin{array}{c}\text { cis - and trans - nonachlor, } \\
\text { oxychlordane) }\end{array}$ & 31.4 & 187 & 66.8 & 309 \\
\hline Dieldrin & 100,000 & 36.0 & 214 & 36 & 167 \\
\hline Endosulfan I & $14 \times 10^{6}$ & 16.9 & 101 & ND & ND \\
\hline Mirex & 500,000 & ND & ND & 17.5 & 81.0 \\
\hline \multicolumn{6}{|c|}{ Dioxins/Furans } \\
\hline OCDD & & ND & ND & 16.0 & 74.1 \\
\hline Total 2378 Substituted Dioxins & & ND & ND & $18.3^{\wedge}$ & 84.7 \\
\hline Total 2378 Substituted TEQ & 1.6 (as TEQ) & $0.038^{\wedge}$ & $0.230^{\wedge}$ & $0.0336^{\wedge}$ & $0.156^{\wedge}$ \\
\hline \multicolumn{6}{|c|}{ PBDES } \\
\hline PBDE-15 & & 8.14 & 48.5 & ND & ND \\
\hline PBDE-17 & & 168 & 1000 & ND & ND \\
\hline PBDE-28 & & 435 & 2590 & 31.5 & 146 \\
\hline PBDE-47 & & 6170 & 36,700 & 848 & 3930 \\
\hline PBDE-49 & & 237 & 1410 & 53.4 & 247 \\
\hline PBDE-66 & & 156 & 929 & ND & ND \\
\hline PBDE-71 & & 24.6 & 146 & ND & ND \\
\hline PBDE-99 & 200,000 & 1090 & 6490 & ND & ND \\
\hline PBDE-100 & & 282 & 1680 & ND & ND \\
\hline PBDE-153 & 500,000 & 13.6 & 81.0 & ND & ND \\
\hline PBDE-154 & & 24.6 & 146 & 35.8 & 166 \\
\hline PBDE-209 & $16.3 \times 10^{6}$ & 506 & 3012 & 275 & 1270 \\
\hline $\begin{array}{l}\text { Total PBDEs (sum of } 37 \\
\text { congeners) }\end{array}$ & & 9110 & 54,300 & 1240 & 5760 \\
\hline \multicolumn{6}{|c|}{ PCBs } \\
\hline Total Monochloro Biphenyls & & NAF & NAF & NAF & NAF \\
\hline Total Dichloro Biphenyls & & NAF & NAF & NAF & NAF \\
\hline Total Trichloro Biphenyls & & 149 & 886 & 294 & 1363 \\
\hline Total Tetrachloro Biphenyls & & 498 & 2970 & 1020 & 4730 \\
\hline Total Pentachloro Biphenyls & & 416 & 2480 & 2950 & 13,700 \\
\hline Total Hexachloro Biphenyls & & 195 & 1160 & 5870 & 27,200 \\
\hline Total Heptachloro Biphenyls & & ND & ND & 1570 & 7270 \\
\hline Total Octachloro Biphenyls & & 25 & 150 & 1110 & 5150 \\
\hline Total Nonachloro Biphenyls & & ND & ND & ND & ND \\
\hline Total Decachloro Biphenyls & & ND & ND & ND & ND \\
\hline $\begin{array}{l}\text { Total PCBs (sum of } 194 \\
\text { Congeners) }\end{array}$ & $\begin{array}{l}50,000 \text { (total: sum of } \\
\text { congeners) }\end{array}$ & 1280 & 7640 & 12,800 & 59,400 \\
\hline
\end{tabular}

^Estimated result: one or more individual isomers used in the summed total concentration is an estimated value greater than the method signal to noise ratio but less than the LOQ. 
in Netarts Bay ranging from 0.027 (total mercury) to 16,600 (aluminum) $\mathrm{mg} / \mathrm{kg}$ dry weight and 12 metals were detected in Coos Bay, ranging from 0.024 (total mercury) to 17,600 (aluminum) $\mathrm{mg} / \mathrm{kg}$ dry weight. The dioxin OCDD was detected at 282 and $295 \mathrm{ng} / \mathrm{kg}$ dry weight at Netarts Bay and Coos Bay, respectively. The dioxin 1,2,3,4,5,6,7,8-HpCDD was detected at 25.4 and $28.1 \mathrm{ng} / \mathrm{kg}$ dry weight at Netarts Bay and Coos Bay, respectively. Percent organic carbon was slightly higher in the sediment collected in Netarts Bay (1.3\%) in comparison with Coos Bay (1.1\%).

Occurrence and concentrations of pesticides, PBDEs, and PCBs in the sediment varied between sites. Nine pesticides were detected in Coos Bay sediments, including four DDT breakdown products (34.9$236 \mathrm{ng} / \mathrm{kg}$ dry weight) and chlordanes. In contrast, only three pesticides were detected in Netarts Bay: two DDT breakdown products at lower concentrations than in Coos Bay, and hexachlorobenzene, which was detected at a concentration more than 50 times higher than in Coos Bay ( 8270 vs. $150 \mathrm{ng} / \mathrm{kg}$ dry weight, respectively).

Similar to oyster tissues, more PCB congeners were detected in Coos Bay (84) than in Netarts Bay (38), resulting in higher concentrations of PCBs in Coos Bay ( $4100 \mathrm{ng} / \mathrm{kg}$ dry weight) as compared to Netarts Bay (1590 ng/kg dry weight). In contrast, PBDEs were detected only in the sediments from Netarts Bay ( 2 detected congeners for a total concentration of $165.3 \mathrm{ng} / \mathrm{kg}$ dry weight).

\subsection{Comparison of oyster tissue and sediment}

The number of compounds detected and concentrations were different in oyster tissue as compared to nearby sediment in both bays. For example, 12 PBDE congeners were detected at much higher concentrations in oyster tissue as compared to two congeners detected at low concentrations in sediment. Of the 12 pesticides detected in oyster tissue, only seven of those also were detected in sediment, and two additional pesticides were detected only in sediment. More PCB congeners were detected and at higher concentrations in oyster tissue than in sediment (Fig. 4). For example, in Netarts Bay (Fig. 4a), 42 PCB congeners were detected in oyster tissue versus 32 in sediment, of which only 24 were common to both matrix types. The eight congeners only detected in sediment were high molecular-weight congeners (PCB-128 and higher). Similarly, in Coos Bay (Fig. 4b), 84 congeners were detected in oyster versus 69 in sediment. Six of the seven congeners only detected in sediment were high molecular-weight congeners (PCB-185 and above). This suggests that the oyster tissue $\mathrm{PCB}$ congener pattern may reflect some degree of degradation to lower molecular-weight congeners during uptake and incorporation into the tissue, whereas the

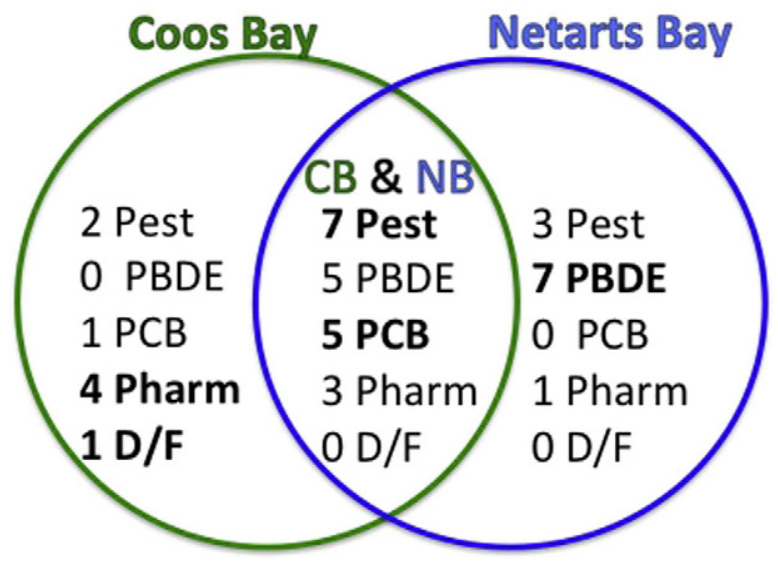

Fig. 2. Overlap of contaminants in oyster tissue by type across Netarts Bay (NB) and Coos Bay (CB) and across the three seasons sampled. The overlap ( $C B$ \&NB) represents the number of compounds found at both sites; outside the overlap is the number of compounds found at one site only. The site(s) with the highest number of contaminants in a category are in bold. Pharm $=$ pharmaceuticals, Pest $=$ pesticides, $\mathrm{D} / \mathrm{F}=$ dioxins furans, PCB refers to biphenyl homolog groups. sediment PCB congener pattern may more closely represent the congener pattern of the PCB sources.

Biota-sediment accumulation factors (BSAFs) compare the concentration of a given contaminant measured in an organism to the concentration of the contaminant measured in the sediment (Shirneshan and Bakhtiari, 2012). Calculated BSAFs were $>2$ for DDTs, chlordanes, PBDEs, and PCBs (Table 7), indicating that oysters are macroconcentrators of these compounds (Franklin et al., 2010). BSAFs for dioxins/furans were $<1$ indicating deconcentration from sediment to biota (Franklin et al., 2010) or a lack of comparability between sediment and tissue concentrations measured in this study. BSAFs for mercury $(\mathrm{Hg})$ were also high. $\mathrm{Hg}$ tends to have high BSAFs for benthic infauna that experience uptake of mercury via direct contact with sediments and pore water, and for fish and other biota that occupy a high trophic position and accumulate $\mathrm{Hg}$ through dietary intake (Taylor et al., 2012).

\section{Discussion}

Contaminant types and concentrations in Olympia oysters and sediments differed substantially between Netarts and Coos Bays, at the sample locations studied (Fig. 2, Tables 4, 5 and 6). Considering all detections, PPCPs were detected more frequently in the samples collected from Coos Bay; surprisingly, compounds that were detected within both estuaries (alkylphenols) occurred at similar concentrations (Table 4). We observed relatively large differences in oyster tissue concentrations of $\mathrm{Hg}$, total PBDEs, and total PCBs between the two estuaries (Table 5). The spatial patterns between CECs and PBDEs differed, while CECs followed a similar pattern to PCBs. Coos Bay had a higher frequency of detection and higher concentrations of CECs, PCBs, and $\mathrm{Hg}$ whereas Netarts Bay had more congeners and higher concentrations of PBDEs. It is notable that the spatial pattern is different for CECs and PBDEs since they are often assumed to derive from a similar wastewater source. This finding indicates that the source of CECs and PCBs to these watersheds may be different than that of PBDEs since the latter compounds can be dispersed through the air as well as through an aqueous medium (USEPA, 2013). The higher concentrations and greater diversity of CEC and PCB compounds in Coos Bay may be attributed to the more urban nature and higher population density (over 25,000 residents) in the Coos Bay area. The urban area comprises $2.6 \%$ of the Coos Bay watershed, whereas urban areas make up less than $1 \%$ of the Netarts watershed $(0.4 \%)$. The source of PBDEs to Netarts Bay is unknown. Since we

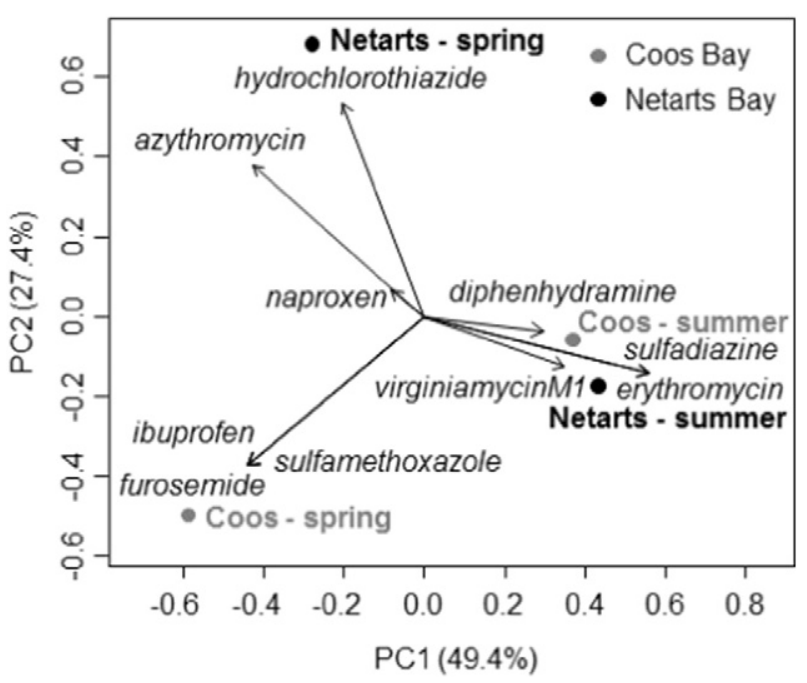

Fig. 3. Principal components analysis (PCA) of pharmaceutical and personal care product concentrations in oyster tissue during spring and summer from Coos Bay (grey) and Netarts Bay (black). Arrows represent specific compounds, whereas circles represent site and season sampling scores. 
Table 6

Concentrations of detected heavy metals and legacy contaminants in sediments collected from Netarts Bay and Coos Bay, OR in summer 2013. ND = not detected; NAF = not analyzed for.

\begin{tabular}{|c|c|c|c|}
\hline \multirow[t]{2}{*}{ Parameter } & \multicolumn{2}{|l|}{ Location } & \multirow[t]{2}{*}{ Units (dry weight) } \\
\hline & Netarts Bay & Coos Bay & \\
\hline Total organic carbon & 1.3 & 1.1 & Percent \\
\hline Percent solids & 59.8 & 72.6 & Percent \\
\hline \multicolumn{4}{|l|}{ Metals } \\
\hline Aluminum, total & 16,600 & 17,600 & $\mathrm{mg} / \mathrm{kg}$ \\
\hline Arsenic, total & 7.14 & 5.81 & $\mathrm{mg} / \mathrm{kg}$ \\
\hline Barium, total & 28.1 & 27.2 & $\mathrm{mg} / \mathrm{kg}$ \\
\hline Chromium, total & 29.9 & 32 & $\mathrm{mg} / \mathrm{kg}$ \\
\hline Cobalt, total & 6.3 & 8.53 & $\mathrm{mg} / \mathrm{kg}$ \\
\hline Copper, total & 10.4 & 17.3 & $\mathrm{mg} / \mathrm{kg}$ \\
\hline Lead, total & 5.17 & 13.2 & $\mathrm{mg} / \mathrm{kg}$ \\
\hline Manganese, total & 145 & 224 & $\mathrm{mg} / \mathrm{kg}$ \\
\hline Mercury, total & 27,000 & 24,000 & $\mathrm{ng} / \mathrm{kg}$ \\
\hline Nickel, total & 16.5 & 36.2 & $\mathrm{mg} / \mathrm{kg}$ \\
\hline Tri-n-butyltin & ND & 2.6 & $\mu \mathrm{g} / \mathrm{kg}$ \\
\hline Zinc, total & 50.6 & 63.8 & $\mathrm{mg} / \mathrm{kg}$ \\
\hline \multicolumn{4}{|l|}{ Pesticides } \\
\hline $2,4^{\prime}-\mathrm{DDD}$ & ND & 65.6 & $\mathrm{ng} / \mathrm{kg}$ \\
\hline $4,4^{\prime}-\mathrm{DDD}$ & 34.0 & 236 & $\mathrm{ng} / \mathrm{kg}$ \\
\hline $4,4^{\prime}-\mathrm{DDE}$ & 70.8 & 91.4 & $\mathrm{ng} / \mathrm{kg}$ \\
\hline $4,4^{\prime}$-DDT & ND & 34.9 & $\mathrm{ng} / \mathrm{kg}$ \\
\hline Alpha-BHC & ND & 25.4 & $\mathrm{ng} / \mathrm{kg}$ \\
\hline Alpha-chlordane & ND & 35.3 & $\mathrm{ng} / \mathrm{kg}$ \\
\hline Beta-BHC & ND & 15.5 & $\mathrm{ng} / \mathrm{kg}$ \\
\hline $\begin{array}{l}\text { Gamma-chlordane }+ \\
\text { trans-nonachlor }\end{array}$ & ND & 57.8 & $\mathrm{ng} / \mathrm{kg}$ \\
\hline Hexachlorobenzene & 8,270 & 150 & $\mathrm{ng} / \mathrm{kg}$ \\
\hline \multicolumn{4}{|l|}{ Dioxins/furans } \\
\hline $1,2,3,4,6,7,8-\mathrm{HpCDD}$ & 25.4 & 28.1 & $\mathrm{ng} / \mathrm{kg}$ \\
\hline $1,2,3,4,6,7,8-\mathrm{HpCDD}$ as TEQ & 0.254 & 0.281 & $\mathrm{ng} / \mathrm{kg}$ \\
\hline OCDD & 282 & 295 & $\mathrm{ng} / \mathrm{kg}$ \\
\hline OCDD as TEQ & 0.0845 & 0.0885 & $\mathrm{ng} / \mathrm{kg}$ \\
\hline Total 2378 substituted dioxins & 307 & 323 & $\mathrm{ng} / \mathrm{kg}$ \\
\hline Total 2378 substituted furans & 3.91 & ND & $\mathrm{ng} / \mathrm{kg}$ \\
\hline Total 2378 substituted TEQ & 0.377 & 0.369 & $\mathrm{ng} / \mathrm{kg}$ \\
\hline \multicolumn{4}{|l|}{ PBDES } \\
\hline PBDE-99 & 138 & ND & $\mathrm{ng} / \mathrm{kg}$ \\
\hline PBDE-153 & 27.3 & ND & $\mathrm{ng} / \mathrm{kg}$ \\
\hline Total PBDEs (sum of 37 congeners) & 165.3 & ND & $\mathrm{ng} / \mathrm{kg}$ \\
\hline \multicolumn{4}{|l|}{ PCBs } \\
\hline Total monochloro biphenyls & NAF & NAF & $\mathrm{ng} / \mathrm{kg}$ \\
\hline Total dichloro biphenyls & NAF & NAF & $\mathrm{ng} / \mathrm{kg}$ \\
\hline Total trichloro biphenyls & 10 & 164 & $\mathrm{ng} / \mathrm{kg}$ \\
\hline Total tetrachloro biphenyls & 227 & 533 & $\mathrm{ng} / \mathrm{kg}$ \\
\hline Total pentachloro biphenyls & 719 & 1010 & $\mathrm{ng} / \mathrm{kg}$ \\
\hline Total hexachloro biphenyls & 528 & 1330 & $\mathrm{ng} / \mathrm{kg}$ \\
\hline Total heptachloro biphenyls & 37 & 597 & $\mathrm{ng} / \mathrm{kg}$ \\
\hline Total octachloro biphenyls & ND & 403 & $\mathrm{ng} / \mathrm{kg}$ \\
\hline Total nonachloro biphenyls & 30 & 30 & $\mathrm{ng} / \mathrm{kg}$ \\
\hline Total decachloro biphenyls & 39 & 32 & $\mathrm{ng} / \mathrm{kg}$ \\
\hline Total PCBs (sum of 194 congeners) & 1590 & 4100 & $\mathrm{ng} / \mathrm{kg}$ \\
\hline
\end{tabular}

only sampled one location in each estuary, there may be withinestuary variability in contaminant type and concentration not accounted for here.

In addition to the differences between locations, the types and concentrations of contaminants detected in oyster tissues differed among the seasonal sampling periods (Fig. 3). The pharmaceuticals detected during summer 2013 (diphenhydramine and naproxen) differed from those detected during spring 2014 (azithromycin and sulfamethoxazole) (Table 4) and no PPCPs were detected during fall 2013. There is little data in the literature on concentrations of pharmaceuticals in oysters. Seasonal differences in contaminant types and concentrations may be due to the combination of variability in use of certain chemicals, different release rates driven by rainfall and processing time in waste treatment systems, and the efficiency with which oysters can both accumulate and depurate organic contaminants within a one to two month period (Sericano et al., 1996). For example, frequently used non-prescription pharmaceuticals such as the anti-inflammatory naproxen and the antihistamine diphenhydramine likely have a pseudo steady-state input into the environment in wastewater effluent from: (1) large, municipal treatment plants; and (2) small private septic systems (e.g., Meador et al., 2016). Both of these compounds were detected in the tissue of Olympia oysters, albeit at low concentrations (naproxen $<2 \mu \mathrm{g} / \mathrm{kg}$ dry weight; diphenhydramine $<0.6 \mu \mathrm{g} / \mathrm{kg}$ dry weight), in multiple seasons. In contrast, prescription pharmaceuticals such as the antibiotics azithromycin and sulfamethoxazole typically are prescribed for a short period of time (10-30 days), therefore their input into the environment is expected to be more sporadic. Seven different prescription pharmaceuticals were each measured once ( 2 detected and 5 estimated) at different times of the year. Seasonal variables (influenza season, storm events, summer visitation at the coast, etc.) may affect the presence and concentrations of these chemicals. In addition, seasonal precipitation may deposit atmospherically-derived chemicals and transport land-derived chemicals into adjacent water bodies, particularly during combined sewer overflow events. However, prolonged precipitation may increase freshwater flows and dilute chemical concentrations in the groundwater, rivers, streams, and estuaries.

Once in the environment, contaminants and other chemicals are subject to transformation by different processes, such as photolysis, volatilization and microbial degradation. In addition, hydrophobic compounds such as PCBs and PBDEs may sorb to sediment which may make them less bioavailable to certain pelagic organisms or more bioavailable to benthic organisms that live or feed near bottom sediment. Native wild-stock Olympia oysters may be exposed to both dissolved and suspended sediment-bound contaminants during filter feeding. Transplanted American oysters (Crassostrea virginica) have been shown to bioaccumulate low molecular weight PCBs at concentrations nearly equal to those of indigenous oysters over a period of 30-48 days. For high molecular weight PCBs, transplanted oysters fail to reach equivalent concentrations after 50 days (Sericano et al., 1996). When oysters are temporarily exposed to PCBs (e.g., congeners 77,126 ), the half-lives of these congeners are reached after 28 and 51 days respectively, due to depuration. Chronically contaminated oysters took 42 and 60 days, respectively, to depurate half of the original concentrations of these two PCBs. Depuration to half the original concentration of tetrachlorinated biphenols, 2,3,7,8-TCDD and 2,3,7,8-TCDF was around 36 days. Oysters take longer to depurate more toxic PCB congeners (Gardinali et al., 2004). These uptake and depuration rates may explain why variability in PPCP types was observed across seasons in the Olympia oysters sampled from Coos and Netarts Bays.

In a companion study, soft shell clams (Mya arenaria) were also collected by ODFW and analyzed by ODEQ concurrently with our analysis of Olympia oysters (ODEQ personal communication). Soft shell clams typically have a lower lipid content (about half) in comparison with the oysters. Soft shell clams collected from Isthmus Slough (a tidal inlet tributary into Coos Bay) contained contaminants similar to those found in the Olympia oysters collected nearby, but the clams had half the concentrations of PCBs and chlordane byproducts of the oysters, likely due to the $50 \%$ lower lipid content in clams. Soft shell clams collected from Isthmus Slough exhibited a greater diversity of PBDEs but at similar concentrations as those found in the oyster tissue, despite the lower lipid content in the clams. Soft shell clams were also collected from Tillamook Bay, a few miles north of Netarts Bay (no clams were collected from Netarts Bay). The soft shell clams from Tillamook Bay had a lipid content about half that of the Netarts Bay oysters, so oysters are expected to have about twice the contaminant concentration as the clams, assuming a consistent regional source. Yet at Netarts Bay, PBDE levels were 8-10 times higher in the oysters than in the soft shell clams from Tillamook Bay, indicating a localized or watershed source of PBDEs into Netarts Bay. PCB congeners were much 
a)

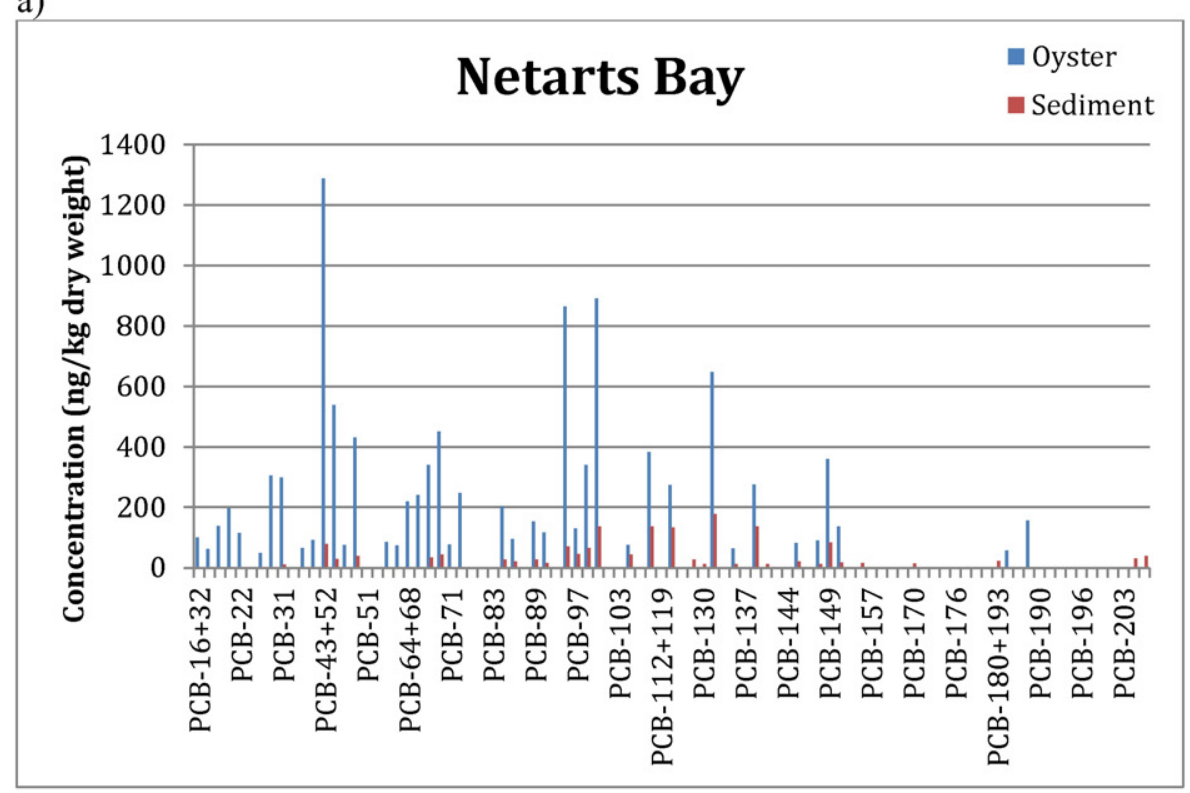

b)

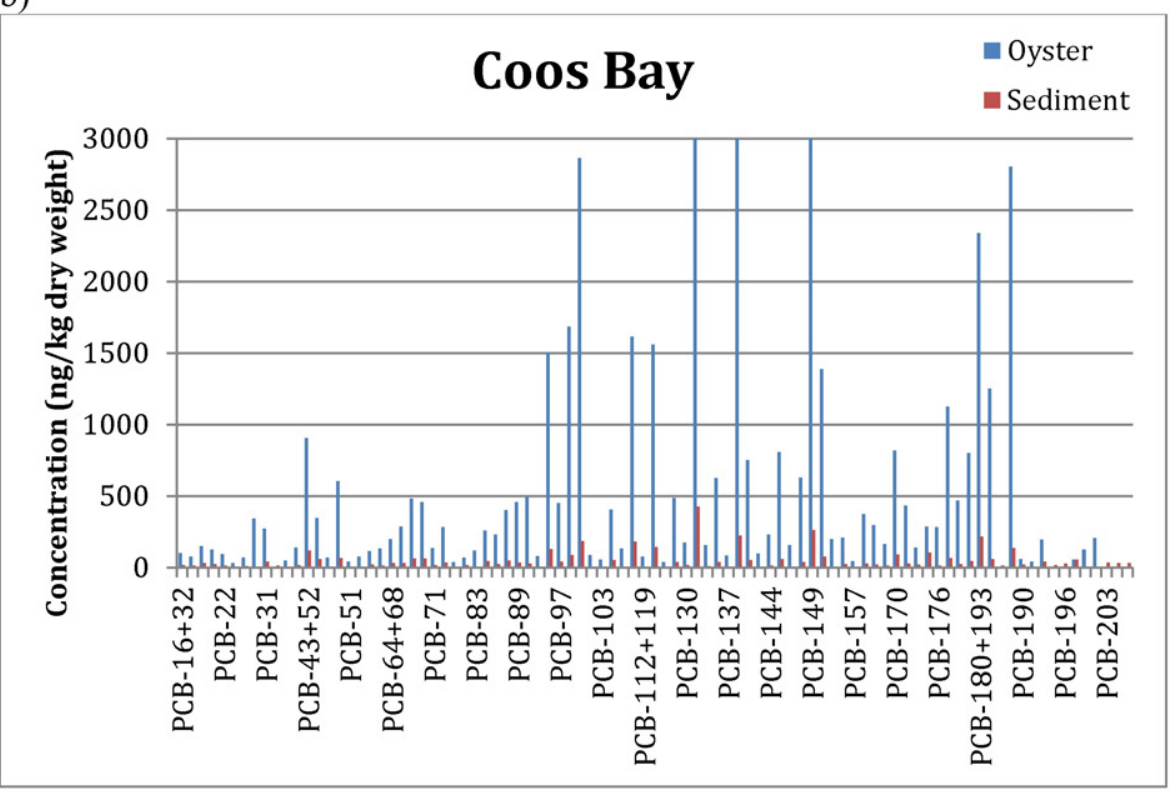

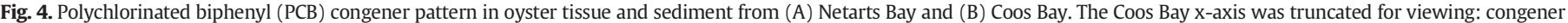
$132+153=9530 \mathrm{ng} / \mathrm{kg}$ dry weight; congener $138+163=4000 \mathrm{ng} / \mathrm{kg}$ dry weight; congener $149=4600 \mathrm{ng} / \mathrm{kg} \mathrm{dry}$ weight.

more diverse in the oysters from Netarts Bay than in the soft shell clams from Tillamook Bay, although tissue levels were comparable after accounting for differences in lipid content (ODEQ, unpublished data).

We are unaware of any data on contaminant classes or concentrations in Ostrea lurida in Oregon or elsewhere. However, similar contaminant classes and concentrations have been measured in several species of oysters (Crassostrea spp.) at locations around the world. The US National Oceanic and Atmospheric Administration (NOAA) Mussel Watch Program measured several contaminants in Crassostrea oysters over 20 years at a number of sites in the Southeastern Atlantic and Gulf of Mexico coastlines. Total DDTs ranged from 1000 to 202,000 ng/kg dry weight (1700$2500 \mathrm{ng} / \mathrm{kg}$ dry weight in our study), PCBs from 4000$157,000 \mathrm{ng} / \mathrm{kg}$ dry weight $(7640-59,400 \mathrm{ng} / \mathrm{kg}$ dry weight in our study), and $\mathrm{Hg}$ from 0 to $330,000 \mathrm{ng} / \mathrm{kg}$ dry weight $(222,000$ $833,000 \mathrm{ng} / \mathrm{kg}$ dry weight in our study) across all oyster sites
(Kimbrough et al., 2008). These levels indicate that Ostrea lurida tissue Hg concentrations in Oregon are high, PCBs are moderate, but DDTs are low in comparison with Crassostrea oysters from the US Atlantic coast and the Gulf of Mexico. Guéguen et al. (2011) report 3000$20,000 \mathrm{ng} / \mathrm{kg}$ of $\mathrm{Hg}$ in oysters sampled from the marketplace in France, lower than in the oysters sampled for this study. Oysters from Arcachon Bay, France had 30,000 ng/kg fresh weight $\mathrm{Hg}$, also lower than those sampled in Oregon; $5.2 \times 10^{3} \mathrm{ng} / \mathrm{kg}$ fresh weight of PCBs (sum of 6 congeners), intermediate between the two sites sampled in Oregon; $2.3 \times 10^{3} \mathrm{ng} / \mathrm{kg}$ fresh weight of DDT/DDE/DDD (sum), comparable to concentrations in Oregon's oysters; and $0.23 \times 10^{3} \mathrm{ng} / \mathrm{kg}$ fresh weight of lindane $(\alpha, \Upsilon-\mathrm{HCH})$ (Devier et al., 2005), higher than the concentrations detected in Olympia oysters from Coos and Netarts Bays. It is worth noting that although Coos Bay is considered urban for the Oregon Coast, with a population density well below 50,000 , it would not be classified as an urban estuary in other US states. 
Table 7

Biota-sediment accumulation factors (BSAFs) for contaminants detected in both sediments and tissues (concentrations in ng/kg, dry weight).

\begin{tabular}{|c|c|c|c|c|c|c|}
\hline \multirow[t]{2}{*}{ Parameter } & \multicolumn{2}{|l|}{ Sediments } & \multicolumn{2}{|l|}{ Tissues } & \multicolumn{2}{|l|}{ BSAF } \\
\hline & Netarts Bay & Coos Bay & Netarts Bay & Coos Bay & Netarts Bay & Coos Bay \\
\hline \multicolumn{7}{|l|}{ Metals } \\
\hline Mercury, total & 27,000 & 24,000 & 833,000 & 222,000 & 30.9 & 9.3 \\
\hline \multicolumn{7}{|l|}{ Pesticides } \\
\hline $2,4^{\prime}-\mathrm{DDD}$ & ND & 65.6 & 87 & 187 & NA & 2.84 \\
\hline $4,4^{\prime}-\mathrm{DDD}$ & 34 & 236 & 288 & 551 & 8.46 & 2.33 \\
\hline $4,4^{\prime}-\mathrm{DDE}$ & 70.8 & 91.4 & 2113 & 977 & 29.8 & 10.7 \\
\hline Alpha-chlordane & ND & 35.3 & 114 & 227 & NA & 6.43 \\
\hline Beta-BHC & ND & 15.5 & 207 & 141 & NA & 9.11 \\
\hline Gamma-chlordane + trans-nonachlor & ND & 57.8 & 187 & 309 & NA & 5.35 \\
\hline \multicolumn{7}{|l|}{ Dioxins/furans } \\
\hline OCDD & 282 & 295 & ND & 74.1 & NA & 0.251 \\
\hline Total 2378 substituted dioxins & 307 & 323 & ND & 84.7 & NA & 0.262 \\
\hline Total 2378 substituted TEQ & 0.377 & 0.369 & 0.226 & 0.156 & 0.67 & 0.422 \\
\hline \multicolumn{7}{|l|}{ PBDEs } \\
\hline PBDE-99 & 138 & ND & 6488 & ND & 47.0 & NA \\
\hline PBDE-153 & 27.3 & ND & 81.0 & ND & 2.97 & NA \\
\hline Total PBDEs (sum of 37 congeners) & 165.3 & ND & 54,256 & 5758 & 328 & NA \\
\hline \multicolumn{7}{|l|}{ PCBs } \\
\hline Total trichloro biphenyls & 10 & 164 & 935 & 1450 & 91.7 & 8.83 \\
\hline Total tetrachloro biphenyls & 227 & 533 & 2966 & 4780 & 13.1 & 8.97 \\
\hline Total pentachloro biphenyls & 719 & 1011 & 2475 & 13,678 & 3.44 & 13.5 \\
\hline Total hexachloro biphenyls & 528 & 1326 & 1161 & 27,191 & 2.20 & 20.5 \\
\hline Total heptachloro biphenyls & 37 & 597 & ND & 7273 & NA & 12.2 \\
\hline Total octachloro biphenyls & ND & 403 & 150 & 5153 & NA & 12.8 \\
\hline Total PCBs (sum of 194 congeners) & 1589 & 4096 & 7688 & 59,526 & 4.84 & 14.5 \\
\hline
\end{tabular}

$\mathrm{BSAF}=$ concentration in biota/concentration in sediment (Shirneshan and Bakhtiari, 2012).

Concentrations of legacy contaminants measured in the oyster tissues from Coos Bay and Netarts Bay were well below Oregon Health Authority screening values designed to protect human health (Table 5; Oregon Health Authority, OHA Environmental Public Health Section, $\mathrm{EPH}, 2013)$. However, there are no federal or state guidelines for CECS such as PPCPs or for cumulative consumption screening values across contaminant types. This is, in part, because different classes of contaminants act on different biological processes, and because little research has examined additive or synergistic effects of lower concentrations of multiple contaminant classes on biological endpoints for marine organisms or humans. Although the detections reported from the present study are well below established screening values, the number of different compounds detected raises the question of whether low concentrations of diverse compounds with different modes of action may be of concern for vulnerable populations.

Variability in contaminant types and concentrations across seasons and between species and media (organisms versus sediment) indicates the limitation of using indicator species, of sampling one medium as a proxy for another, and/or of sampling only annually to determine contaminant loads at a given site or for specific species. These findings highlight the need for better metrics to determine contaminant concentrations across time and space. The compound mixtures detected within two Oregon estuaries elucidate the need to develop models that identify potential thresholds of compound mixtures to safeguard ecological communities and human health. Given the serious decline in populations of native Olympia oysters along the Pacific coast, future research could examine whether environmental contaminants should be considered as an additional stressor contributing to their decline.

Our new data provide a baseline for contaminant concentrations in sediments and Olympia oyster tissue within two Oregon estuaries. As coastal populations grow and the use of prescription and nonprescription pharmaceuticals continues to rise (Gu et al., 2010), it is increasingly important to develop effective monitoring strategies and tools to detect changes and understand the effects of multiple contaminants on marine organisms and the humans who consume them.

\section{Acknowledgements}

This work was made possible through funding from Oregon Sea Grant in the form of Program Development Grant \#NA154C-A to EFG; Contaminants Grant \#NA10OAR4170059 to EFG, ALS, WF, KEC, EBN, LP, SSR and through funding from the Oregon Community Foundation in the form of an Oregon University System Katherine Bisbee II Grant to EFG and AMF. We thank Oregon Sea Grant and the Oregon Community Foundation for their support. We thank ODEQ Laboratory for analytical support and Tony D'Andrea and ODFW staff for assistance in the field. The field and lab work would not have been possible without assistance from the following PSU undergraduate and graduate students: Dylan Dayrit, Dominic Galen, Andy Harwood, Joey Peters, Emma Prichard, and Brianna Tarnower.

\section{Appendix A. Supplementary data}

Supplementary data to this article can be found online at http://dx. doi.org/10.1016/j.scitotenv.2016.03.043.

\section{References}

Barnes, K.K., Kolpin, D.W., Meyer, M.T., Thurman, E.M., Furlong, E.T., Zaugg, S.D., Barber L.B., 2002. Water-quality Data for Pharmaceuticals, Hormones, and Other Organic Wastewater Contaminants in U.S. Streams, 1999-2000. U.S. Department of the Interior (Open-File Report 02-94).

Beck, M., Brumbaugh, D.R., Airoldi, L., Carranza, A., Coen, L.D., Crawford, C., Defeo, O. Edgar, G.J., Hancock, B., Kay, M.C., Lenihan, H.S., Luckenback, M.W., Toropova, C.L., Zhang, G., Guo, X., 2011. Oyster reefs at risk and recommendations for conservation, restoration, and management. Bioscience 61, 107-116.

Conn, K.E., Siegrist, R.L., Barber, L.B., Meyer, M.T., 2010. Fate of trace organic compounds during vadose zone soil treatment in an onsite wastewater system. Environ. Toxicol. Chem. 29, 285-293.

Development Core Team, R., 2015. R: A Language and Environment for Statistical Computing. R Foundation for Statistical Computing, Vienna, Austria.

Devier, M.H., Augagneur, S., Budzinski, H., Le Menach, K., Mora, P., Narbonne, J.F., Garrigues, P., 2005. One-year monitoring survey of organic compounds (PAHs, PCBs, TBT), heavy metals and biomarkers in blue mussels from the Arcachon bay, France. J. Environ. Monit. 7, 224-240. 
Fleming, L.E., Broad, K., Clement, A., Dewailly, E., Elmir, S., Knap, A., et al., 2006. Oceans and human health: emerging public health risks in the marine environment. Mar. Pollut. Bull. 53, 545-560.

Franklin, E.B., Yap, C.K., Ismail, A., 2010. Bioaccumulation and distribution of heavy metals $(\mathrm{Cd}, \mathrm{Cu}, \mathrm{Fe}, \mathrm{Ni}, \mathrm{Pb}$ and $\mathrm{Zn})$ in the different tissues of Chicoreus capucinus Lamarck (Mollusca: Muricidae) collected from Sungai Janggut, Kuala Langat, Malaysia. Environ. Asia 3, 65-71.

Gardinali, P.R., Sericano, J.S., Wade, T.L., 2004. Uptake and depuration of toxic halogenated aromatic hydrocarbons by the American oyster (Crassostrea virginica): a field study. Chemosphere 54, 61-70.

Gaw, S., Thomas, K.V., Hutchinson, T.H., 2014. Sources, impacts and trends of pharmaceuticals in the marine and coastal environment. Philos. Trans. R. Soc. B 369, 20130572

Glassmeyer, S.T., Furlong, E.T., Kolpin, D.W., Cahill, J.D., Zaugg, S.D., Werner, S.L., Meyer, M.T., Kryak, D.D., 2005. Transport of chemical and microbial compounds from known wastewater discharges: potential for use as indicators of human fecal contamination. Environ. Sci. Technol. 39, 5157-5169.

$\mathrm{Gu}$, et al., 2010. Centers for disease control and prevention. NCHS Data Brief. No. 42, pp. $1-8$

Guéguen, M., Amiard, J.C., Arnich, N., Badot, P.M., Claisse, D., et al., 2011. Shellfish and residual chemical contaminants: hazards, monitoring, and health risk assessment along French coasts. Rev. Environ. Contam. Toxicol. 213, 55-111. http://dx.doi.org/10.1007/ 978-1-4419-9860-6 3.

Hope, B.K., Pillsbury, L., Boling, B., 2012. A state-wide survey in Oregon (USA) of trace metals and organic chemicals in municipal effluent. Sci. Total Environ. 417-418, 263-272.

Kidd, K.A., Blanchfield, P.J., Mills, Palace, V.P., Evans, R.E., Lazorchak, J.M., Flick, R.W., 2007 Collapse of a fish population after exposure to a synthetic estrogen. PNAS 104, 8897-8901.

Kimbrough, K.L., Johnson, W.E., Lauenstein, G.G., Christensen, J.D., Apeti, D.A., 2008. An Assessment of Two Decades of Contaminant Monitoring in the Nation's Coastal Zone. NOAA Technical Memorandum, Silver Spring, MD (NOS NCCOS 74. 105 pp).

MEA (Millenium Ecosystem Assessment), 2005. Ecosystems and Human Well-being: Current State and Trends. Island Press, Washington, D.C.

Meador, J.P., Yeh, A., Young, G., Gallagher, E.P., 2016. Contaminants of emerging concern in a large temperate estuary. Environ. Pollut. 213, 254-267.

Morace, J.L., 2012. Reconnaissance of contaminants in selected wastewater-treatmentplant effluent and stormwater runoff entering the Columbia River, Columbia Rive Basin, Washington and Oregon, 2008-10. U.S. Geological Survey Scientific Investigations Report 2012-5068, p. 68

Nilsen, E.B., Zaugg, S., Alvarez, D.A., Morace, J.L., Waite, I.R., Counihan, T.D., Hardiman, J.M., Torres, L., Patiño, R., Mesa, M., Grove, R., 2014. Contaminants of legacy and emerging concern in largescale sucker (Catostomus macrocheilus) and the foodweb in the lower Columbia River, Oregon and Washington, USA. Sci. Total Environ. 484, 344-352.

Oregon Department of Environmental Quality, 2015. Wastewater permit database. Accessed 2 September 2015. URL: http://www.deq.state.or.us/wq/sisdata/sisdata.asp.

Oregon Department of Environmental Quality (ODEQ), 2003. Fact Sheet: Sources of Polychlorinated Biphenyls. PCB Fact Sheet.CP.8.6.03 (http://www.deq.state.or.us/lq/ $\mathrm{cu} / \mathrm{nwr} /$ PortlandHarbor/docs/SourcePCBs.pdf)

Oregon Health Authority (OHA) Environmental Public Health Section (EPH), 2013S. Current Oregon Fish Advisories and Consumption Guidelines (accessed XX/XX/15).
Paul, J.H., Rose, J.B., Jiang, S.C., Zhou, X.T., Cochran, P., Kellogg, C., Kang, J.B., Griffin, D., Farrah, S., Lukasik, J., 1997. Evidence for groundwater and surface marine water contamination by waste disposal wells in the Florida keys. Water Res. 31, 1448-1454.

Pillsbury, L.A., Goodwin, K., Brown, D., 2015. Statewide Water quality toxics assessment report. ODEQ Technical Report. DEQ15-LAB-0065-TR (26 pp.)

Rodriguez del Rey, Z., 2010. Occurrence and Concentrations of Caffeine in Seawater From the Oregon Coast and Potential Effects on the Dominant Mussel, Mytilus californianus. Portland State University, MS Thesis.

Rumrill, S., 2010. Restoration of native Olympia oysters within the South Slough estuary. Final Project Report for NOAA Restoration Center Community-based Restoration Pro$\operatorname{gram}(31 \mathrm{pp}$.$) .$

Schreder, E.D., La Guardia, M.J., 2014. Flame retardant transfers from U.S. households (dust and laundry wastewater) to the aquatic environment. Environ. Sci. Technol. 48, 11575-11583.

Sericano, J.L., Wade, T.L., Brooks, J.M., 1996. Accumulation and depuration of organic contaminants by the American oyster (Crassostrea virginica). Sci. Total Environ. 179, $149-160$

Shirneshan, G., Bakhtiari, A.R., 2012. Accumulation and distribution of $\mathrm{Cd}, \mathrm{Cu}, \mathrm{Pb}$ and $\mathrm{Zn}$ in the soft tissue and shell of oysters collected from the northern coast of Qeshm Island, Persian Gulf, Iran. Chem. Speciat. Bioavailab. 24, 129-138.

Taylor, D.L., Linehan, J.C., Murray, D.W., Prell, W.L., 2012. Indicators of sediment and biotic mercury contamination in a southern New England estuary. Mar. Pollut. Bull. 64, 807-819. http://dx.doi.org/10.1016/j.marpolbul.2012.01.013.

U.S. Census Bureau, 2008. American Housing Survey for the United States: 2007; Table 1A-4 Selected Equipment and Plumbing Current Housing Reports Series H150/07, Washington, DC

UNEP, 2006. Marine and Coastal Ecosystems and Human Well-being: A Synthesis Report Based on the Findings of the Millennium Ecosystem Assessment. UNEP (76 pp.).

USDA [US Department of Agriculture], 2015. Watershed Boundary Dataset. Coordinated effort between the United States Department of Agriculture-Natural Resources Conservation Service (USDA-NRCS), the United States Geological Survey (USGS), and the Environmental Protection Agency (EPA) (accessed 16/11/2015, http:// datagateway.nrcs.usda.gov)

USEPA, 2000. Guidance for assessing chemical contaminant data for use in fish advisories. Fish Sampling and Analysis, third ed. EPA 823-B-00-007 vol. 1.

USEPA, 2009. Classification of Regional Patterns of Environmental Drivers and Benthic Habitats in Pacific Northwest Estuaries (EPA 600/R-09/140).

USEPA, 2013. Contaminants of Emerging Concern (CECS) in Fish: Polybrominated Diphenyl Ethers (PBDEs) (EPA-820-F-13-003)

Vajda, A.M., Barber, L.B., Gray, J.L., Lopez, Woodling, J.D., Norris, D.O., 2008. Reproductive disruption in fish downstream from an estrogenic wastewater effluent. Environ. Sci. Technol. 42, 3407-3414. http://dx.doi.org/10.1021/es0720661.

Wasson, K. Zabin, C. Bible, J., Briley, S., Ceballos, E., Chang, A., Cheng, B., Deck, A., Grosholz, T., Helms, A., Latta, M., Yednock, B., Zacherl, D., Ferner, M., 2015. A Guide to Olympia Oyster Restoration and Conservation. Elkhorn Slough National Estuarine Research Reserve. J.T, Litho.

White, J.M., Buhle, E.R., Ruesink, J.L., Trimble, A.C., 2009. Evaluation of native oyster (Ostrea lurida) status and restoration techniques in Puget Sound, Washington, USA. J. Shelliish Res. 28, 107-112. 